\title{
Comparison between Volatile Oil from Fresh and Dried Fruits of Zanthoxylum rhetsa (Roxb.) DC. and Cytotoxicity Activity Evaluation
}

\author{
Sewan Theeramunkong ${ }^{1}$, Maleeruk Utsintong ${ }^{2, *}$
}

\section{Sewan Theeramunkong ${ }^{1}$, Maleeruk Utsintong ${ }^{2, *}$}

${ }^{1}$ Faculty of Pharmacy, Thammasat University, 99 Moo 18 Phahonyothin Road, Klongluang, Pathumthani, 12120, THAILAND.

${ }^{2}$ School of Pharmaceutical Sciences, University of Phayao, 19 Moo 2 Lumpang-Phayao Road, Mueang, Phayao 56000, THAILAND.

Correspondence

\section{Dr. Maleeruk Utsintong}

Department of Pharmaceutical Care, School of Pharmaceutical Sciences, University of Phayao, 19 Moo 2 Lumpang-Phayao Road, Mueang, Phayao 56000, THAILAND.

Phone No: (+66) 56-466666

E-mail: maleeruk.ut@up.ac.th

\section{History}

- Submission Date: 31-01-2018;

- Review completed: 05-03-2018;

- Accepted Date: 03-05-2018

\section{DOI : 10.5530/pj.2018.5.141}

Article Available online

http://www.phcogj.com/v10/i5

\section{Copyright}

(C) 2018 Phcog.Net. This is an openaccess article distributed under the terms of the Creative Commons Attribution 4.0 International license.

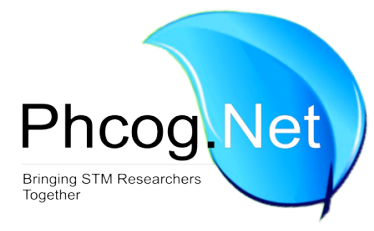

\begin{abstract}
Introduction: Zanthoxylum rhetsa is a tree found in northern Thailand. It has been used as a traditional herb with medicinal properties. However, the comparison of composition in volatile oil from fresh and dried fruit is still not fully investigated. In study, we evaluated the constituents in oil from fruits of $Z$. rhetsa and evaluated the cytotoxicity in non-small lung cancer cells. Methods: The hydro distillation was applied to afford the oil. The obtained oil was analyzed by GC-MS and evaluated the cytotoxicity and apoptosis in non-small lung cells by using MTT method and flow cytometry respectively. Results: Fresh and dried fruits provided a higher yield of volatile oil by approximately $10 \%$ and $20 \%$ respectively, compared to other studies. Twenty-eight compounds were identified and the major components of fresh and dried fruits were not distinctly different. The major component, $\alpha$-limonene, was found in dried fruits from Phayao, southern Nan and Chiang Rai province. A high content of $\beta$-phellandrene was found in dried fruits from northern Nan province and the (+)-sabinene was found in high content of fresh fruits from southern Nan, Phayao and Chaing Rai province. Furthermore, the cytotoxicity tests displayed that all of oil products were active against lung cancer cells. Among the components investigated, fresh and dried fruits from southern Nan province showed to be the most potent $\left(E_{50}=1.91 \pm 0.53,1.79 \pm 0.43 \mu \mathrm{L} / \mathrm{mL}\right.$, respectively). Conclusion: Volatile oil of $Z$. rhetsa exhibited a strong cytotoxic properties against cytotoxic may be potentially used as natural anticancer agents.
\end{abstract}

Key words: Zanthoxylum rhetsa, Local variation, Volatile oil, Chemical composition, Cytotoxic activity.

\section{INTRODUCTION}

The Rutaceae family is distributed throughout the tropical areas of the world and it is composed of more than 1500 species. ${ }^{1}$ Most species of Rutaceae are fragrant plants, medium-sized trees at 5-10 meter-height. Many extracts from Rutaceae have been shown to possess biological activities such as antioxidant, ${ }^{2}$ antimicrobial $^{3}$ and antifungal. ${ }^{4}$ The Zanthoxylum, a member of genus in Rutaceae, is used as traditional medicine, seasoning, perfume and other purposes. Zanthoxylum rhetsa is one species found in northern Thailand, locally called "Makhwaen". Numerous research papers have reported interesting pharmacological activities from various parts of $Z$. rhetsa such as toothache, ${ }^{5}$ inhibitory activity against leukemia cells (HL-60). ${ }^{6}$ The petroleum ether extract and essential oil from the fruit has been reported as green mosquito repellent and larvicidal agent. ${ }^{7-8}$ In addition, other researchers described the activity of this volatile oil as antioxidant, ${ }^{2}$ antimalarial, ${ }^{9}$ antimicrobial ${ }^{10}$ In addition, Some constituents of essential oil had been reported to possess anticancer activities such as limonene, carvacrol, sabinene, $\alpha$-pinene, myrcene, $\gamma$-terpinene, thujones and etc. The anticancer mechanisms were considered through the antioxidant, antimutagenic, antiproliferative and enhancement of immune system. ${ }^{11}$

Recently, it was reported a hydrodistillation approach to afford essential oil from $Z$. rhetsa analyzed with GC-MS. ${ }^{12}$ However, there are no detailed studies which compared the essential oils from fresh and dried fruits of $Z$. rhetsa. In this research, we performed eco-friendly extraction by using hydro distillation to obtain the volatile oil, conducting from plant samples selection from four different areas in northern Thailand, an investigation into the compositions of fresh and dried fruits. In addition, we have evaluated the cytotoxicity against a non-small lung cancer cell line.

\section{MATERIALS AND METHODS}

\section{Plant Material}

The fruits were gathered from four different regions in Thailand; northern and southern Nan province, 
Phayao province and Chiang Rai province. The collection period was from October to December in 2014. The plant sample was identified as Zanthoxylum rhetsa (Roxb.) DC. A voucher specimen (No.039023) was referenced at CMU Herbarium, Faculty of Science, Chiang Mai University, Thailand.

Fruits were dried in an oven with a constant temperature of $45^{\circ} \mathrm{C}$ for $24 \mathrm{~h}$ until constant weight. Then the products were finely grounded before tested. Even fresh fruits were finely grounded to use.

\section{Chemical and Solvents}

Sodium chloride, potassium chloride, disodium phosphate and potassium dihydrogen phosphate were of analytical grade. $N, N$-Dimethyl sulfoxide were of biological reagent grade.

\section{Extraction and isolation}

Fresh and dried fruits $(500 \mathrm{~g})$ were put into hydrodistillation for $6 \mathrm{~h}$. The volatile oil was dried over anhydrous sodium sulfate. The oil was kept at $4^{\circ} \mathrm{C}$ in a refrigerator before analyses.

\section{Fourier transform infrared spectroscopy (FTIR) analysis}

FTIR spectrum of the volatile oil was obtained by ATR technique using IRTracer-100 Shimadzu FTIR spectrometer. The spectrum of volatile oil was taken from $4000 \mathrm{~cm}-1$ to $650 \mathrm{~cm}-1$ wave number range. The spectrum obtained was compared among different sources.

\section{Gas Chromatography-Mass Spectrometry (GC-MS) analysis}

The GC-MS analysis of volatile oil was performed using a GC 7890A Agilent interfaced to a mass spectrometer MSD5975C (EI) Agilent. The experiment was conducted on a $5 \mathrm{MS}$ capillary column $(30 \mathrm{~m} \mathrm{x} 0.25 \mathrm{~mm}$ ID $\times 0.25 \mu \mathrm{m}$ film thickness). The temperature of GC injection inlet was $250^{\circ} \mathrm{C}$. Then the column oven was programmed at $60^{\circ} \mathrm{C}(0 \mathrm{~min})$, then increased by $3^{\circ} \mathrm{C}$ per min to $240^{\circ} \mathrm{C}(0 \mathrm{~min})$. The total run time was $60 \mathrm{~min}$. The injection volume was $0.5 \mu \mathrm{L}$ and split ratio injection was 50:1. Helium was used as the carrier gas at constant flow-rate of $1.0 \mathrm{~mL} / \mathrm{min}$. The temperature of MS quadrupole was $150^{\circ} \mathrm{C}$ after injection. The ion source temperature was set at $230^{\circ} \mathrm{C}$. The electron impact ionization mode was operated at $70 \mathrm{eV}$; fragment mass range, 30-500 amu. The mass of each compound was compared with mass spectra of references or Wile libraries or database of National Institute Standard and Technology (NIST) having more than 62,000 patterns. The spectrum of the unknown components were compared with the spectrum of known components stored in the NIST library.

\section{Biological test}

\section{Cell culture}

H460 cells (Human large cell lung cancer cell line) were cultured by using Roswell Park Memorial Institute (RPMI) 1640 Medium with L-glutamine (Biowest, France). Whereas MRC-5 cells (Human fibroblast cell lung normal cell line) were cultured by using Eagle's Minimum Essential Medium (EMEM) with sodium bicarbonate, non-essential amino acids, L-glutamine, and sodium pyruvate (Corning Inc., USA). To prepare testing cells, both media were supplemented with $10 \%$ fetal bovine serum (Biowest, France), $100 \mathrm{U} \cdot \mathrm{mL}^{-1}$ Penicillin and $100 \mu \mathrm{g} / \mathrm{mL}$ Streptomycin (Gibco, Life Technologies Inc., USA). The cells were cultured under $5 \% \mathrm{CO}_{2}$ humidified incubator at $37^{\circ} \mathrm{C}$.

\section{Assessment of cytotoxic activity}

All the volatile oils were determined for cytotoxicity in both $\mathrm{H} 460$ and MRC-5 cell line. Each cells were seeded in separated 96 well microtiter plates at a concentration of 10,000 cells/well in suitable medium as above mention. After 24-h incubation, cells were treated with presence or absence of different concentration of volatile oil and incubated for $24 \mathrm{~h}$ at $37^{\circ} \mathrm{C}$ with $5 \% \mathrm{CO}_{2}$. On the experimental day, cells were washed with phosphate buffer solution and $90 \mu \mathrm{L}$ of PBS containing $0.5 \mathrm{mg} / \mathrm{mL}$ of MTT (3-(4, 5-dimethylthiazol-2-yl)-2, 5-diphenyltetrazolium bromide)) was added to each well and incubated for $4 \mathrm{~h}$ at $37^{\circ} \mathrm{C}$. Then the solution was removed and $100 \mu \mathrm{L}$ of DMSO were added. The plates were shaken well and measured with spectrophotometric microplate reader at $570 \mathrm{~nm}$ within $30 \mathrm{~min}$. The optical density (OD) was obtained using Infinite M200 Pro Nano quant Absorbance Micro plate Reader obtained from Tecan Group Ltd. (Switzerland) at wavelength of $570 \mathrm{~nm}$. The relative cell viability was expressed as a percentage relative to the untreated control cells as following equation:

$$
\text { Cell viability }(\%)=\frac{\text { ODtreated }- \text { ODblank }}{\text { ODuntreated }- \text { ODblank }} \times 100
$$

After the percentage of cell viability was calculated, then the mean growth-inhibitory concentration $\left(\mathrm{IC}_{50}\right.$ ) values were plotted and fitted using the Prism software version 5.01.

\section{Morphology of treated cancer cell}

Morphology of $\mathrm{H} 460$ cells were determined after treatment with volatile oil of Zanthoxylum rhetsa in three separated 96 well microtiter plates at a concentration of 10,000 cells/well in RPMI supplemented with $10 \%$ FBS, penicillin $(100 \mu \mathrm{g} / \mathrm{mL})$, and streptomycin $(100 \mu \mathrm{g} / \mathrm{mL})$. After $24-\mathrm{h}$ incubation, cells were treated with presence or absence of a fixed concentration of extracted volatile oils. After 18-h incubation, the medium was discarded and was washed the cells twice with cold phosphate buffer. The resulting cells were added with binding buffer $(50 \mu \mathrm{L})$ and stained with Annexin V-FitC and propidium bromide (FitC Annexin V apoptosis detection kit I, BD Bioscience). The cells were examined by using IN cell Analyzer 2000 (GE healthcare company, USA)

\section{Flow cytometric analysis (FACS)}

Some active volatile oils were chosen to investigate the apoptosis mechanism of $\mathrm{H} 460$ cell by using flow cytometer. After 18-h incubation, cells were stained by FitC Annexin V apoptosis detection kit I and followed BD Bioscience protocol. The stained cells were then analyzed by using BD FACSVerse (BD Bioscience, USA)

\section{RESULTS}

\section{Extraction and isolation}

The results showed that the volatile oil obtained from dried fruits from various areas displayed higher yields than those obtained from fresh fruits. The highest yield of volatile oil was obtained from dried fruits of Southern Nan (Table 1).

The GC-MS analysis of volatile oil obtained from fresh and dried fruits and the mass spectra of all compounds are illustrated in Table 2. The chromatogram shows twenty seven known compounds and one unknown as noted no attempts to identify the unknown compound were performed. The major component of oil obtained from fresh fruits from Phayao and

Table 1: Yield of volatile oil from Fresh and dried fruits.

\begin{tabular}{ccccc}
\hline \multirow{2}{*}{ Type of fruit } & \multicolumn{5}{c}{ Yield of volatile oil (\% v/w) } \\
\cline { 2 - 5 } & NN & NS & PY & CR \\
\hline Fresh fruit & 11.80 & 13.60 & 8.10 & 8.30 \\
Dried fruit & 14.17 & 15.33 & 13.17 & 13.83 \\
\hline
\end{tabular}

(NN: oil derived from northern Nan, NS: oil derived from southern Nan, PY: oil derived from Phayao and CR: oil derived from Chiang Rai) 
Table 2: The composition of oil obtained from fresh and dried fruits via GC-MS method.

\begin{tabular}{|c|c|c|c|c|c|c|c|c|c|c|}
\hline \multirow{3}{*}{ No. } & \multirow{3}{*}{ RT } & \multirow{3}{*}{ Compounds } & \multicolumn{8}{|c|}{$\%$ Relative area } \\
\hline & & & \multicolumn{2}{|c|}{ NN } & \multicolumn{2}{|c|}{ NS } & \multicolumn{2}{|c|}{ PY } & \multicolumn{2}{|c|}{ CR } \\
\hline & & & Fresh & Dried & Fresh & Dried & Fresh & Dried & Fresh & Dried \\
\hline 1 & 4.3 & Thujen & 0.38 & 0.34 & 0.65 & 0.14 & 0.60 & 0.63 & 0.47 & 0.22 \\
\hline 2 & 4.5 & a.Pinene & 8.83 & 8.68 & 5.89 & 5.88 & 5.68 & 5.99 & 1.46 & 7.36 \\
\hline 3 & 5.4 & Sabinene & 0.63 & 0.68 & 26.89 & 0.42 & 25.03 & 25.11 & 31.21 & 0.87 \\
\hline 4 & 5.5 & b.Pinene & 0.23 & 0.22 & - & - & - & - & - & 0.17 \\
\hline 5 & 5.9 & b.Myrcene & 7.42 & 6.96 & 4.40 & 4.56 & 4.74 & 4.55 & 2.41 & 5.59 \\
\hline 6 & 6.3 & a.Phellandrene & 22.45 & 19.40 & 12.45 & 10.88 & 11.87 & 11.06 & 2.32 & 16.65 \\
\hline 7 & 6.4 & 3-Caren & 1.45 & 1.42 & 0.71 & 0.67 & 0.79 & 0.83 & - & - \\
\hline 8 & 6.6 & a.Terpinene & - & - & 0.40 & - & 0.36 & 0.38 & - & - \\
\hline 9 & 6.9 & o-Cymene & 2.11 & 4.09 & 2.91 & - & 2.77 & 3.49 & - & - \\
\hline 10 & 7.0 & b.Phellandrene & 28.75 & 29.70 & 21.61 & - & - & - & - & - \\
\hline 11 & 7.1 & Limonene & - & - & - & 59.68 & 27.10 & 28.90 & 49.09 & 52.19 \\
\hline 12 & 7.2 & trans-arOcimene & 5.02 & 4.70 & 2.69 & 3.03 & 2.70 & 2.67 & 1.00 & 3.44 \\
\hline 13 & 7.6 & (E)-bEOcimene & 9.84 & 9.23 & 9.56 & 11.30 & 9.53 & 8.41 & 8.86 & 7.84 \\
\hline 14 & 7.9 & g.Terpinen & - & - & 0.87 & - & 0.70 & 0.82 & 0.49 & 0.95 \\
\hline 15 & 8.9 & a.Terpinolen & 0.35 & 0.28 & - & - & 0.31 & 0.29 & - & - \\
\hline 16 & 9.3 & Linalool & 1.83 & 1.40 & 1.03 & 0.46 & 0.97 & 0.99 & - & - \\
\hline 17 & 10.5 & Limonene oxide & - & - & - & - & - & - & - & 0.23 \\
\hline 18 & 12.2 & 1-Terpinen-4-ol & - & - & 2.11 & - & 1.98 & 2.17 & 0.92 & - \\
\hline 19 & 12.7 & b2Fenchyl alcohol & 1.02 & 1.05 & 1.83 & - & 1.87 & 1.80 & - & - \\
\hline 20 & 13.4 & Decanal & 1.17 & 1.26 & - & - & - & - & - & - \\
\hline 21 & 13.6 & 2-Ethyl hexyl acetate & 4.33 & 4.87 & - & - & - & - & - & - \\
\hline 22 & 19.8 & 1-Methoxy-2-methylthiobenzene & - & - & 0.80 & - & - & - & - & - \\
\hline 23 & 19.8 & Unknown & - & - & - & 0.73 & 0.73 & - & - & - \\
\hline 24 & 20.7 & Lavandulyl acetate & 2.41 & 3.35 & - & - & 0.66 & 0.28 & - & - \\
\hline 25 & 21.8 & b1Caryophyllen & 1.23 & 1.82 & 1.45 & 1.01 & 0.69 & 0.71 & 0.40 & 1.05 \\
\hline 26 & 24.3 & Germacrene d & 0.54 & 0.55 & 3.10 & 1.09 & 0.92 & 0.90 & 1.37 & 2.83 \\
\hline 27 & 24.9 & Bicyclogermacrene & - & - & 0.65 & - & - & - & - & 0.42 \\
\hline 28 & 28.0 & Spathulenol & - & - & - & 0.14 & - & - & - & 0.21 \\
\hline
\end{tabular}

(NN: oil obtained from northern Nan, NS: oil obtained from southern Nan, PY: oil obtained from Phayao and CR: oil obtained from Chiang Rai), RT = retention time (min)

Chiang Rai was a-limonene (27.10 and 49.09\%, respectively). Similar results were also obtained dried fruits (28.90 and 52.19\%, respectively).

The major component of the oil obtained from both fresh fruits and dried fruits from northern Nan was $\beta$-phellandrene. However, the major components of the oil obtained from both fresh fruits and dried fruits from southern Nan were (+)-sabinene and $\alpha$-limonene.

\section{Fourier transform infrared spectroscopy (FTIR) analysis}

All volatile oils were analyzed by FTIR instrument. The results were displayed spectrum from different sources provide same figure print pattern. (Figure 1)

\section{Biological test}

All volatile oils were tested for cytotoxicity against non-small lung cancer cells (H460 cell-line) and lung normal cells (MRC-5 cell line). The results indicated that all volatile oils obtained from fresh fruits and dried fruits were cytotoxic against lung cancer. The cytotoxicity results of all oil samples obtained from both fresh fruits and dried fruits showed slightly different activity against lung cancer cell. Among all samples, it was found the oil obtained from dried fruits of southern of Nan exhibited the best inhibitory effect on the growth of $\mathrm{H} 460$ cells $\left(\mathrm{EC}_{50} 1.79 \mu \mathrm{L} / \mathrm{mL}\right)$. For cytotoxicity against MRC-5 cells, the oil samples revealed wide range of $\mathrm{EC}_{50}$ value, ranging from $2.03 \mu \mathrm{L} / \mathrm{mL}$ to $7.07 \mu \mathrm{L} / \mathrm{mL}$. Our research group also calculated the selectivity index (SI) of oil samples. The SI index was determined by the $\mathrm{EC}_{50}$ ratio of tested oil against cancer cells and normal cells. Among the oil samples obtained fresh fruits and dried fruits, the $\mathrm{SI}_{s}$ of oil obtained from fresh fruits from northern of Nan, southern of Nan and Chiang Rai were shown the high selectivity with 2.86, 1.92 and 1.81 $\mu \mathrm{L} / \mathrm{mL}$, respectively (Table 3 , Figure 2 ).

In the addition, the morphology of untreated H460 cells and treated cell with oil samples at concentration of $2 \mu \mathrm{L} / \mathrm{mL}$ was also examined. After $18 \mathrm{~h}$ of the treatment, the cell was stained with Annexin V-FitC and propidium bromide to investigate the change of membrane in early or late apoptosis stage and nuclei in cell lysis stage, respectively. The images 
exhibited the untreated cells, showed a high confluency of monolayer cells, typical growth patterns and a smooth, flattened morphology with normal nuclei. The cells that were treated with oil samples displayed the abnormal morphology changing from round shapes to deformed cell membrane as shown in bright filed view and fluorescent view (Figure 3). Furthermore, we also examined apoptosis via Annexin V-Fit C and PI staining by FACS analysis (Figure 4). Cells were treated with oil obtained from fresh fruits from Chiang Rai. The H460 cells grown in the presence or absence of oil sample for $18 \mathrm{~h}$ were washed once in PBS trypsinize to harvest the cells and centrifuge. The resulting cells were washed once

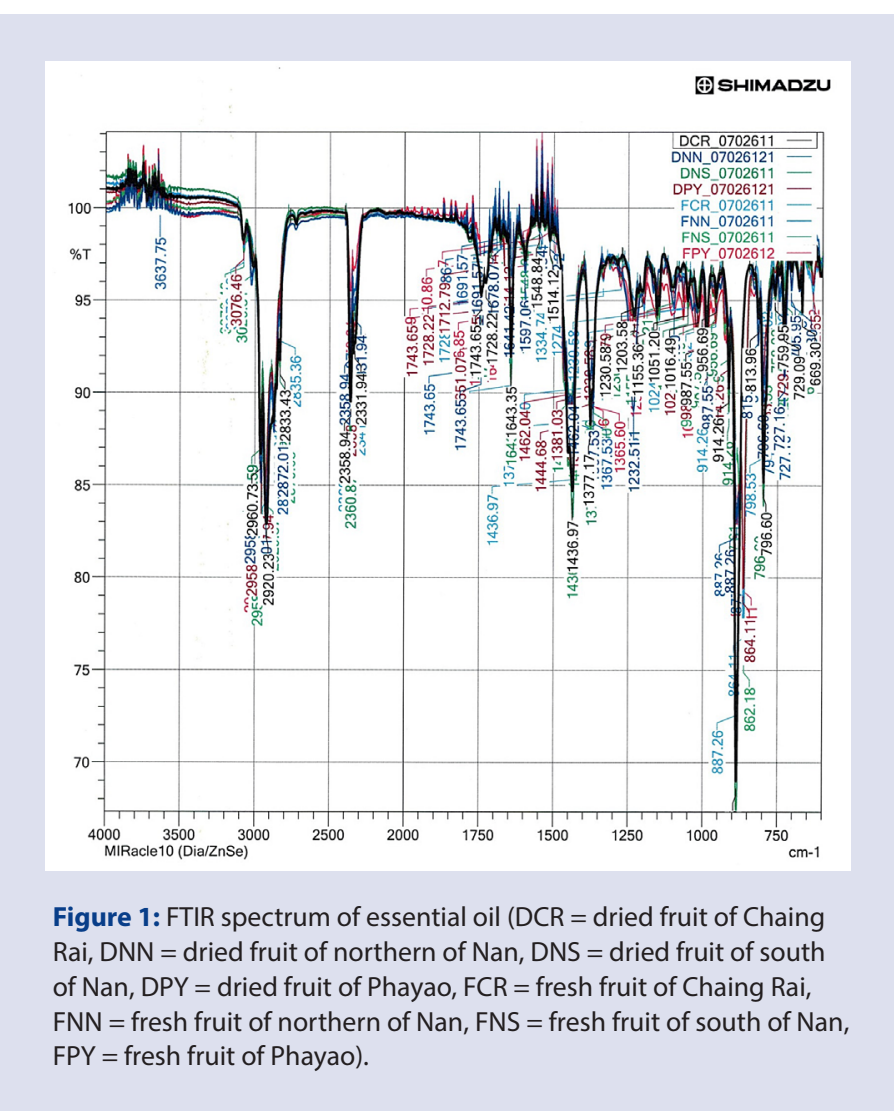

Table 3: $\mathrm{EC}_{50}$ of volatile oil from fresh and dried fruit against $\mathrm{H} 460$ cells and MRC- 5 cells and selectivity index (SI).

\begin{tabular}{ccccccc}
\hline \multirow{3}{*}{ Sample } & \multicolumn{2}{c}{$\mathrm{H} 460$} & \multicolumn{2}{c}{$\mathrm{MRC}-5$} & \multicolumn{2}{c}{$\mathrm{SI}{ }^{* *}$} \\
& \multicolumn{2}{c}{$\mathrm{EC}_{50}^{*}(\mu \mathrm{L} / \mathrm{mL}) \pm \mathrm{SD}$} & \multicolumn{2}{c}{$\mathrm{EC}_{50}^{*}(\mu \mathrm{L} / \mathrm{mL}) \pm \mathrm{SD}$} & & \\
\cline { 2 - 7 } Fresh & Dried & Fresh & Dried & Fresh & Dried \\
\hline \multirow{2}{*}{$\mathrm{NN}$} & $2.47 \pm$ & $2.83 \pm$ & $7.07 \pm$ & $2.38 \pm$ & 2.86 & 0.84 \\
& 0.09 & 0.41 & 0.72 & 0.36 & & \\
$\mathrm{NS}$ & $1.91 \pm$ & $1.79 \pm$ & $3.66 \pm$ & $2.06 \pm$ & 1.92 & 1.15 \\
& 0.53 & 0.43 & 1.29 & 0.17 & & \\
PY & $2.37 \pm$ & $2.00 \pm$ & $2.41 \pm$ & $2.03 \pm$ & 1.02 & 1.02 \\
& 0.13 & 0.47 & 0.17 & 0.22 & & \\
CR & $2.09 \pm$ & $2.09 \pm$ & $3.78 \pm$ & $2.45 \pm$ & 1.81 & 1.17 \\
\multirow{3}{*}{ Doxorubicin } & 0.40 & 0.42 & 1.10 & 0.64 & & \\
\hline
\end{tabular}

${ }^{*} \mathrm{EC}_{50}$ values represent the calculated $\mathrm{EC}_{50}$ values for volatile oil. Data presented $\mathrm{EC}_{50}$ values in mean $\pm \mathrm{SD}$ of at least 3 determinations from separate experiments. ${ }^{*} \mathrm{SI}$ is the selectivity index equal to $\mathrm{EC}_{50}$ of tested compound in a normal cell line $/ \mathrm{EC}_{50}$ of the same tested compound in cancer cell line

*** $\mathrm{The}_{50}$ value from research reference ${ }^{15}$

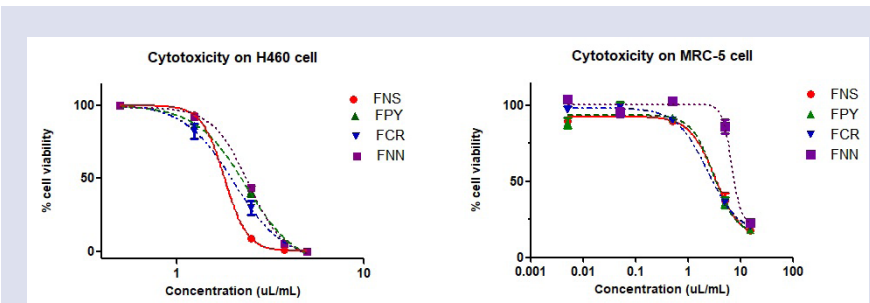

Figure 2: Concentration-response curve of the oil derived from fresh fruit on a) cancer cell line, H460 (b) on normal lung cell line (MRC-5). Values are mean of at least three determinations from separate experiments. (FNN = fresh fruit of northern of Nan, FNS = fresh fruit of south of Nan, FPY = fresh fruit of Phayao, FCR = fresh fruit of Chaing Rai).

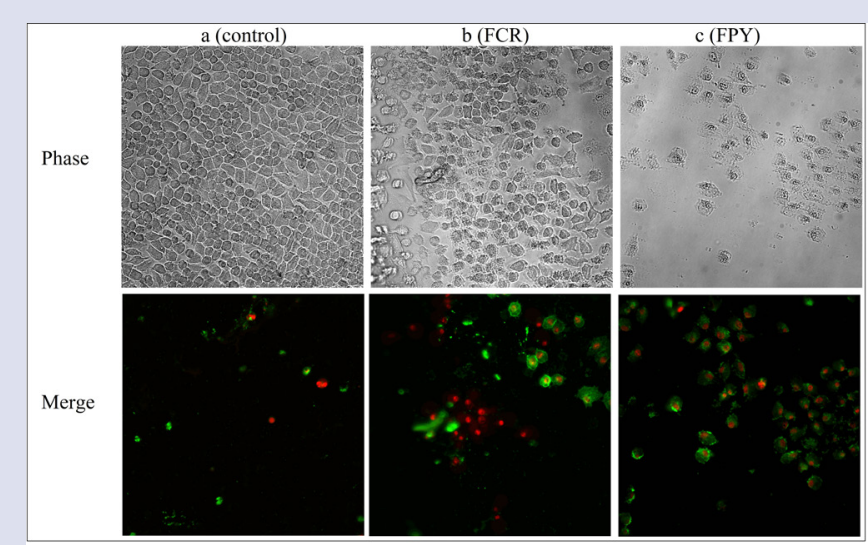

Figure 3: Phase-contrast images and fluorescence image (x40) of $\mathrm{H} 460$ cells at approximate logarithmic phase after 18-h treatment with a) vehicle, b) oil obtained from fresh fruits of Chiang Rai (FCR), c) oil obtained from fresh fruits of Phayao (FPY). The cancer cell was exposed to Annexin V-Fit C and propidium iodide and appear green- and red-staining, respectively.

with cold PBS and finally re-suspend cells with binding buffer to obtain approximate $1 \times 10^{6}$ cells $/ \mathrm{mL}$. The harvested cellular DNA were stained with Annexin V-Fit C/PI.

From FACS analysis, the dual parametric dot plots of oil derived from Chiang Rai-treated cells displayed the mainly late apoptotic cells in the upper right quadrant (UR) and low population in the early apoptotic cells in the lower right quadrant (LR), whereas the control showed the viable cell population in the lower left quadrant. These preliminary results show the oil may induce apoptosis in tumor cells.

\section{DISCUSSION}

The oil derived from various areas displayed different chemical constituents. The major composition was monoterpenes and the others were oxygenated monoterpene, oxygenated sesquiterpene and hydrocarbon. It was found that monoterpenes such as limonene and sabinene have been report to have antioxidant. ${ }^{2}$ Antioxidants are agents that protect the body from oxidative stress which lead to molecular damages, cardiovascular diseases and cancer. ${ }^{13}$ From southern Nan, the constituents in oil from fresh fruits and dried fruits were distinctly different. The GC-MS results showed nineteen analytes in fresh fruit but only fourteen analytes in dried fruit. The reason was possibly due to the evaporation during the drying process. 


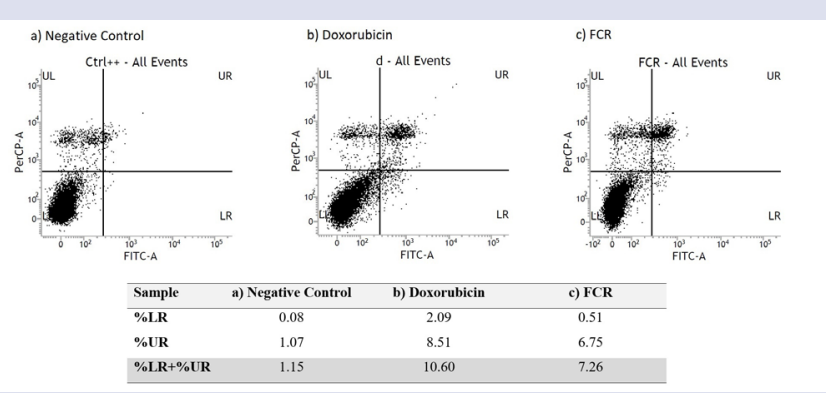

Figure 4: Flow cytometric analysis (FACS) of the distribution of $\mathrm{H} 460$ cells treated with the a) negative control b) doxorubicin c) oil sample derived from FCR, Annexin V-PI analysis in $\mathrm{H} 460$ cells, following $18 \mathrm{~h}$ of compound treatment by Annexin-V-FITC method at IC ${ }_{50}$ concentrations, which are $0.15 \mu \mathrm{M}$ and $2 \mu \mathrm{L} / \mathrm{mL}$, respectively. Results are representative of one of three independent experiments

SI value displayed the differential cytotoxic activity performance of the tested sample against cancer and normal cells. ${ }^{14}$ The high SI value indicates a higher selectivity for cytotoxic activity against $\mathrm{H} 460$ cells than MRC- 5 cells.

\section{CONCLUSION}

In this manuscript, we collected oil from fresh and dried fruits of Zanthoxylum rhetsa from different part of Thailand. We determined the composition of the oil, showing that the major components are a-limonene (Phayao, southern Nan and Chiang Rai), $\beta$-phellandrene (northern Nan) and (+)-sabinene (southern Nan).

In addition, the volatile oil showed considerably cytotoxic activity against lung cancer cell, H460 and some oil samples obtained from fresh fruit had tendency to be more selectivity on cancer cell. The cytotoxic activity possibly from some essential oil possessing anticancer properties and this is an interesting outcome which will lead us to further study in deep the biological activity of individual components.

The principle of Annexin V-Fit C staining is based on the change of membrane. When the cell are undergo apoptosis, the lipid phospatidylserine is translocate and lead to bind with Annexin V-Fit C and show the green staining. In addition, propidium iodide (PI) is a popular red fluorescent to distinct between viable and necrosis cell. PI is able to stain DNA nucleus or DNA-containing organelles in which late apoptosis or dead cells.

\section{ACKNOWLEDGEMENT}

This study was supported, in part, by financial support from faculty of pharmacy, Thammasat University (research project grant 2/59) and from University of Phayao (grant number UoE58003). The authors thank to
Prof. Dr. Opa Vajragupta (department of pharmaceutical chemistry) and Dr. Supachoke Mangmool (department of pharmacology) from Mahidol University for their facility supports, biological suggestions and their assistances.

\section{CONFLICT OF INTEREST}

There is no conflict of interest.

\section{ABBREVIATIONS}

CR: Oil derived from Chiang Rai; FCR: Fresh fruit of Chaing Rai; FNN: Fresh fruit of northern of Nan; FNS: Fresh fruit of south of Nan; FPY: Fresh fruit of Phayao; NN: Oil derived from northern Nan; NS: Oil derived from southern Nan; PY: Oil derived from Phayao; RT: Retention time.

\section{REFERENCES}

1. Pollio A, De NA, Appetiti E, Aliotta G, Touwaide A. Continuity and change in the Mediterranean medical tradition: Ruta spp. (rutaceae) in Hippocratic medicine and present practices. J Ethnopharmacol. 2008;116(3):469-82.

2. Tangjitjaroenkun1 J, Supabphol R, Chavasiri W. Antioxidant effect of Zanthoxylum Limonella Alston. J Med Plants Res. 2012;6(8):1407-14.

3. Esterhuizen LL, Meyer R, Dubery IA. Antimicrobial compounds from Coleonema album (Rutaceae). Z Naturforsch C. 2006;61(7-8):489-98.

4. Balakumar S, Rajan S, Thirunalasundari T, Jeeva S. Antifungal activity of Aegle marmelos (L.) Correa (Rutaceae) leaf extract on dermatophytes. Asian Pac J Trop Biomed 2011;1(4):309-12

5. Ganesan S. Traditional oral care medicinal plants survey of Tamil Nadu. Nat Prod Radiance 2008;7(2):166-72.

6. Jiwajinda S, Santisopasri V, Murakami A, Kim O, Kim HW, Ohigashi H. Suppressive effects of edible Thai plants on superoxide and nitric oxide generation. Asian Pac J Cancer Prev. 2002;3(3):215-23.

7. Das NG, Baruah I, Talukdar PK, Das SC. Evaluation of botanicals as repellents against mosquitoes. J Vect Borne Dis. 2003;40(1/2):49-53.

8. Rabha B, Gopalakrishnan R, Baruah I, Singh L. Larvicidal activity of some essential oil hydrolates against dengue and filariasis vectors. Eur $\mathrm{J}$ Med Res. 2012;1(1):14-6.

9. Charoenying P, Laosinwattana C, Phuwiwat W, Lomratsiri J. Biological activities of Zanthoxylum limonella Alston fruit extracts. KMITL Sci J. 2008;8(1):12-5.

10. Wannissorn B, Jarikasem S, Siriwangchai T, Thubthimthed S, Thubthimthed S Antibacterial properties of essential oils from Thai medicinal plants. Fitoterapia. 2005;76(2):233-6.

11. Bhalla Y, Gupta VK, Jaitak V. Anticancer activity of essential oils: A review. Journal of the Science of Food and Agriculture. 2013;93(15):3643-53.

12. Bubpawan $P$, Boonphong S, Sriwattanawarunyoo C, Udeye V. Characterization of the Essential oil and Fatty oil from Makhwaen Fruit (Zanthoxylum rhetsa (Roxb.) DC) NU Int J Sci. 2016;12(1):1-10.

13. Birben E, Sahiner UM, Sackesen C, Erzurum S, Kalayci O. Oxidative stress and antioxidant defense. World Allergy Organ J. 2012;5(1):9-19.

14. Badisa RB, Darling-Reed SF, Joseph P, Cooperwood JS, Latinwo LM, Goodman CB. Selective cytotoxic activities of two novel synthetic drugs on human breast carcinoma MCF-7 cells. Anticancer Res. 2009;29(8):2993-6.

15. Lee CL, Lin YT, Chang FR, Chen GY, Backlund A, Yang JC, et al. Synthesis and Biological Evaluation of Phenanthrenes as Cytotoxic Agents with Pharmacophore Modeling and ChemGPS-NP Prediction as Topo II Inhibitors. PLoS ONE. 2012;7(5):e37897.

Cite this article: Theeramunkong S, Utsintong M. Comparison between Volatile Oil from Fresh and Dried Fruits of Zanthoxylum rhetsa (Roxb.) DC. and Cytotoxicity Activity Evaluation. Pharmacog J. 2018;10(5):827-32. 
GRAPHICAL ABSTRACT

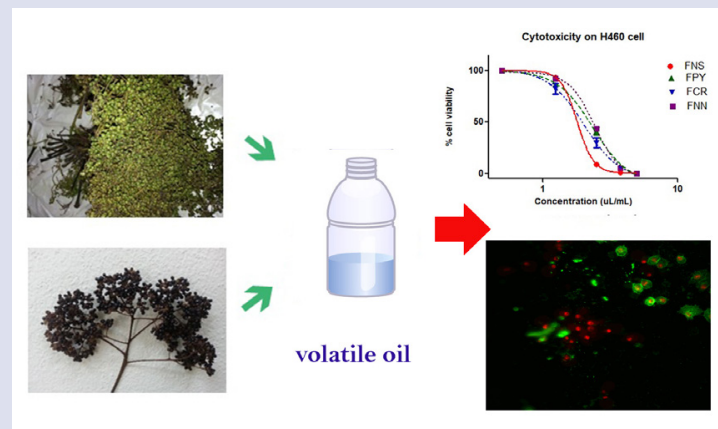

\section{SUMMARY}

- Twenty-eight compounds were identified from the volatile oil of Zanthroxylum rhetsa (Roxb.) DC. fruits.

- The oil was analyzed by GC-MS technique and found that limonene, $\beta$-phellandrene and sabinene were the major components.

- The volatile oil exhibited a strong cytotoxicity against $\mathrm{H460}$ human large cell lung cancer cell line.

\section{ABOUT AUTHORS}

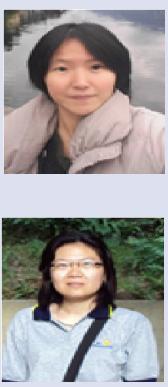

Dr. Sewan Theeramunkong Working as a Assistant Professor in Division of Pharmaceutical Science, Faculty of Pharmacy, Thammasat University, Thailand. Her research area is the synthesis of bioactive compounds and discovery of novel scaffold for antitumoral agents. In addition, she also examines the anticancer properties of some traditional medical plants in Thailand. Recently, she has been interested in synthesis of compounds with antimalarial activity.

Dr. Maleeruk Utsintong Working as a Assistant Professor and Researcher at the School of Pharmaceutical Sciences, University of Phayao, Thailand. Her research involves drug design, synthesis of compounds, bioactivity and phytochemical studies resulting over 10 publications, 3 books and a petty patent. 